\title{
3D printing applications during COVID-19 pandemic: a literature review
}

\author{
As aplicações da impressão 3D durante a pandemia \\ de COVID-19: uma revisão da literatura
}

\author{
Giovanna Barbosa Brito de Sousa BIONE ${ }^{1}$ iD https://orcid.org/0000-0003-3099-2349 \\ Jéssyca Maria França de Oliveira MELO² iD https://orcid.org/0000-0001-8777-847X \\ Francine Queiroz PEREIRA ${ }^{1}$ iD https://orcid.org/0000-0001-5147-9443 \\ Felipe Rodrigues de ALMEIDA² iD https://orcid.org/0000-0003-1084-5085 \\ Renata Cimões Jovino SILVEIRA² iD https://orcid.org/0000-0003-3673-8739 \\ Bruna de Carvalho Farias VAJGEL² iD https://orcid.org/0000-0002-2756-0767
}

\begin{abstract}
The fast spread of COVID-19 around the world has generated significant impacts on the way societies lives, one of which is the scarcity of personal protective equipment (PPE) for workers in the front lines of combat against the virus. Sanitary insecurity has led populations and health professionals to a rampant search for protective equipment and other devices necessary for life maintenance, both for patients and professionals, revealing health system limitations during large-scale crisis, as the COVID-19 pandemic. On this paper, we aimed to present the initiatives of professionals and companies related to 3D printing to share programs and resources whose purpose is supplying workers in the front line, who have been important allies in combating the effects caused by coronavirus. A search was performed in four electronic databases: SCOPUS, BVS, EMBASE and MEDLINE via PUBMED. After analyzing the inclusion and exclusion criteria, a table of results was prepared with the main characteristics of the products manufactured and made available, as well as the institutions involved. It was concluded, therefore, that the applications of 3D printing in the initiatives had great contributions to public health and the additive industry during the pandemic period of COVID-19.
\end{abstract}

Indexing terms: Coronavirus infections. Personal protective equipment. Three-dimensional printing.

\section{RESUMO}

A rápida disseminação da COVID-19 ao redor do mundo gerou significativos impactos no modo de viver das sociedades, sendo um deles, a escassez de equipamentos de proteção individual (EPIS) para trabalhadores que atuam na linha de frente no combate ao vírus. A insegurança sanitária levou populações e profissionais da saúde a uma busca desenfreada por equipamentos de proteção, além de

$\boldsymbol{\nabla} \nabla \boldsymbol{\nabla}$

1 Universidade Federal de Pernambuco, Curso de Odontologia. Av. Prof. Moraes Rego, 1235, 50670-420, Cidade Universitária, Recife, PE, Brasil. Correspondence to: BCF VAJGEL. E-mail: <bruna_farias@hotmail.com>.

2 Universidade Federal de Pernambuco, Programa de Pós-graduação em Odontologia. Recife, PE, Brasil.

$\boldsymbol{\nabla} \boldsymbol{\nabla} \boldsymbol{\nabla}$

How to cite this article

Bione GBBS, Melo JMFO, Pereira FQ, Almeida FR, Silveira RCJ, Vajgel BCF. 3D printing applications during COVID-19 pandemic: a literature review. RGO, Rev Gaúch Odontol. RGO, Rev Gaúch Odontol. 2021;69:e2021006. http://dx.doi.org/10.1590/1981-86372021000620200168 
outros aparatos necessários à manutenção da vida, tanto dos pacientes, quanto dos profissionais, revelando as limitações dos sistemas de saúde diante de crises em grande escala, como a pandemia da COVID-19. Buscou-se, por meio do presente trabalho, apresentar as iniciativas de profissionais e empresas relacionadas à impressão 3D de compartilharem programas e recursos com o intuito de abastecer trabalhadores na linha de frente, que têm sido importantes aliados no combate aos efeitos provocados pelo novo coronavírus. Para isso, foi realizada uma pesquisa em quatro bases de dados eletrônicas, sendo elas: SCOPUS, BVS, EMBASE e MEDLINE via PUBMED. Após análise dos critérios de inclusão e exclusão, foi confeccionada uma tabela de resultados com as principais características dos produtos fabricados e disponibilizados, assim como a instituição envolvida. Concluiu-se, portanto, que as aplicações da impressão 3D nessas iniciativas tiveram grandes contribuições para a saúde pública e a indústria aditiva durante o período da pandemia da COVID-19.

Termos de indexação: Infecções por coronavirus. Equipamento de proteção individual. Impressão tridimensional.

\section{INTRODUCTION}

The new coronavirus is responsible for an intense sanitary and social economic crisis that plagues countries in the entire world. The growing number of cases and the collapse of health systems are evident, which requires fast actions of prevention and combat regarding the spreading of the disease [1].

Health professionals who work in the front-line taking care of people infected by the virus are the most susceptible to contamination due to the direct contact with the etiological agent, being at high occupational risk. This way, individual protection with correct and reliable equipment is crucial to prevent the contamination of these professionals, who are key elements on the articulation to the pandemic combat [2].

The high necessity of prevention, triggered the pursuit for personal protection equipment (PPE), both on part of the civil society and of the health professionals' staff. The latter, however, with the urgency of the use of some specific prevention tools, that soon became insufficient. To minimize the scarcity of these utensils, technologies and 3D printing equipment were introduced as complementary to the manufacture of PPEs and other medical/hospital resources, that are also highly important to the care of the Covid-19 patient [3].

$3 \mathrm{D}$ printing is a robotic technology that allows the fabrication of items through the deposition of biomaterials in a personalized manner, using computer pre-manufactured projects [3].

Therefore, the present study has as an objective, to expose the efforts of institutions and individuals regarding the application of 3D printing as a supplier of resources and of personal protection equipment for health professionals, who work in the front line of the combat against the new coronavirus.

The narrative revision of the literature was done through the database: SCOPUS, BVS, EMBASE and MEDLINE via PUBMED. The search strategy used was of free and controlled terms, divided in 3 parts. First, the population: (Dentists) OR (Dentistry); Second, term related to the intervention to be revised: (Three-Dimensional Printing); and, finally, the defining terms of the final outcomes: "COVID-19" [Supplementary Concept] OR (2019 novel coronavirus disease) OR (covid-19) OR (covid-19 pandemic) OR (sars-cov-2 infection) OR (covid-19 virus disease) OR (2019 novel coronavirus infection) OR (2019-ncov infection) OR (coronavirus disease 2019) OR (coronavirus disease-19) OR (2019-ncov disease) OR (covid-19 virus infection). The operator AND was used to combine the groups.

As an inclusion criteria, the papers should: a) approach the applications of 3D printing for the confection of medical/hospital resources during the new Coronavirus pandemic; b) be available in accessible languages to the authors, such as Portuguese, English or Spanish; and c) have been published between January and May 2020.

After the use of the terms specified on the research of the databases, millions of scientific articles, in many science areas, were found. Thus, the articles that made reference to $3 \mathrm{D}$ printing in other moments that were not the Covid-19 pandemic, were excluded. The studies about other diseases, were also excluded. According with the inclusion criteria, 16 published papers on the period between January and May 2020 were maintained, they significantly contributed to the construction of the present study of narrative revision of literature.

\section{Covid-19 and the biosecurity of health professionals}

The new coronavirus disease (COVID-19) has affected numerous countries around the world, being classified as a pandemic by the World Health Organization (WHO), on March 12, 2020. As a result, a state of insecurity and fear was created all over the world, causing 
behavior changes on the populations and governments in an attempt to mitigate the sanitary and social economic effects [1].

The Severe Acute Respiratory Syndrome -Coronavirus-2 (SARS-CoV-2), virus that causes COVID-19, has a much bigger power of reach, when compared to oter coronaviruses already identified, for it has a high level of propagation. Although it is a real threat and there is high probability of new outbreaks, the preventive measures and treatment of the current virus are still limited [4].

Its transmission happens through the respiratory tract, through the contact with droplets coming from respiratory secretions of contaminated people, and through the contact with contaminated surfaces. The incubation period is of 3 to 7 days in average, being able to achieve 14 days, stage on which a contaminated person can transmit the disease to the people, even when this person is asymptomatic, that is to say, when this person doesn't have symptoms. The elderly and people with chronic diseases or with morbidities, such as, hypertension, chronic obstructive pulmonary disease (COPD), diabetes, cardiovascular disease, obesity, cancer and immunologic debility, besides being predisposed to acquire the infection, are more likely to develop severe forms of the disease [2]. This is why basic measures of hygiene, especially the cleansing of the hands and social distancing are crucial for the combat to the unrestrained propagation of the virus $[5,6]$.

The health professionals are the ones who have the greatest risk of contracting the disease for being in direct contact with contaminated patients, therefore it is essential to ensure their biosecurity during the attendances [2]. Just by the PPEs, used as a barrier between the professionals and the microorganisms and with the objective of avoiding unwanted infections, they are protected. And these tools, among them the respiratory protective masks, with high power of filtration of aerosols (N95, N99, N100, PFF2 or PFF3), waterproof cloak, gloves and eye protection glasses and facial masks/ facial shields, must be used by the entire staff, especially during pandemics $[2,6,7]$.

However, the great demand of the population for these PPEs, in midst of the panic provoked by lack of knowledge of the disease, in a short amount of time, caused the scarcity of these items in hospitals, besides causing a deficit on the distribution of the companies and the exorbitant increase in prices, creating anxiety and fear among the health professionals around the world $[3,6,8]$.
In some places, due to the critical moment, there was the need to rationing and reutilization of the PPEs in the front line of acting against the new coronavirus, disrespecting the sanitary standards. Health professionals from New York city - USA, for instance, came to the point of using raincoats and garbage bags, due to the lack of appropriate protection [9].

\section{D printing at health's service}

The industrial recession and the difficulties in supplying the demand of the health systems for PPEs and other medical resources, provoked a mobilization of companies, hospitals, researches and civil society, by means of choosing fast initiatives of material supply, such as 3D printing, on the attempt to solve such need $[1,4,10,11]$.

$3 \mathrm{D}$ printing is a technique of additive fabrication that, based in computer design, allows the physical production of models through the addition of layers of dome material, through a printing machine, in a fast way and economically viable [12].

On the scope of $3 \mathrm{~d}$ printing, there are basically two types of printers: one works with filaments and another which works with resin. The first one is similar to a hot glue pistol of fast cooling, assembled on axes $X-Y-Z$, on which a software Slicer captures a tridimensional file and develops guidance for the printing equipment, which traces the path that the head of printing will do for, systematically, deposit individual layers of the material and, finally, obtain the finalized piece $[13,14]$.

The second type of $3 d$ printer uses a tank of resinous monomers reactive to ultraviolet radiation (UV) coupled to a liquid crystal display (LCD), to block or allow the passage of UV light through the guidance of a software, which informs the needed standard of exposition of the resin to the UV rays necessary to obtain the object $[13,14]$.

$3 \mathrm{D}$ printing technology began to be used in medicine with the objective of promoting improvements on the scopes of education and diagnose and patient treatments [1]. Nowadays, it is used on the confection of anatomic models and surgical guides to planning and trans-operative guidance, with success in maxillofacial and orthopedic surgeries. However, due to the current sanitary crises, the technology is being used to supply medical/ hospital resources, such as PPEs [9]. 


\section{Specific applications of 3D printing in the combat against COVID-19}

$3 \mathrm{D}$ printing is being used on the fabrication of several items needed in the combat of the pandemic, such as PPEs, nasal and oropharyngeal swabs of flexible polymers and production of valves for mechanical ventilators [15]. It is estimated that there are approximately $444.0003 \mathrm{D}$ printers, only in the United States and 168.000 in the United Kingdom, what reinforces that companies and amateur users of this technology may help ensuring sufficient items to the health staff in a short period of time [6].

At Sistema Único de Saúde (SUS) - Brazilian public health system, 3D printing labs also created a schedule to supply the shortage of material resources at Brazilian public hospitals. Among the fabrication items there are, facial shields, technical prototype of breathing mask with filter element, cloak with sealing system, reusable surgical masks, adapters for greater comfort for facial masks, safety glasses and components of mechanical ventilators [15].

An important factor to be mentioned is that the effectiveness and security of the majority of the equipment projected and printed by the 3D printing segment during the pandemic may not have been strictly tested, due to the urgency of the health system needs. Thus, it is crucial that the 3D printing communities commit themselves to ensure that the fabricated items are secure, or at least more secure than the option of not using them [1].

Many prototypes of PPEs and other items needed for the demands of hospitals in the front line were made available free of charge through social media. There was a substantial increase on their use, due to social distancing $[6,14]$.

Those who take an interest in helping to supply the shortage of medical/hospital resources through 3D printing, should virtually look for a project approved by regulation sanitary authorities and print a prototype that will be tested by health professionals. Then, adjustments will be made, in case it's necessary, and then, a higher quantity will be liberated for printing [6].

The most popular item, that has many shared designs on the internet, is te facial protector or shield. The equipment must follow the quality standards, such as the safe ventilation permission, not to be produced with irritation material and has to be comfortable to the user $[9,12]$.

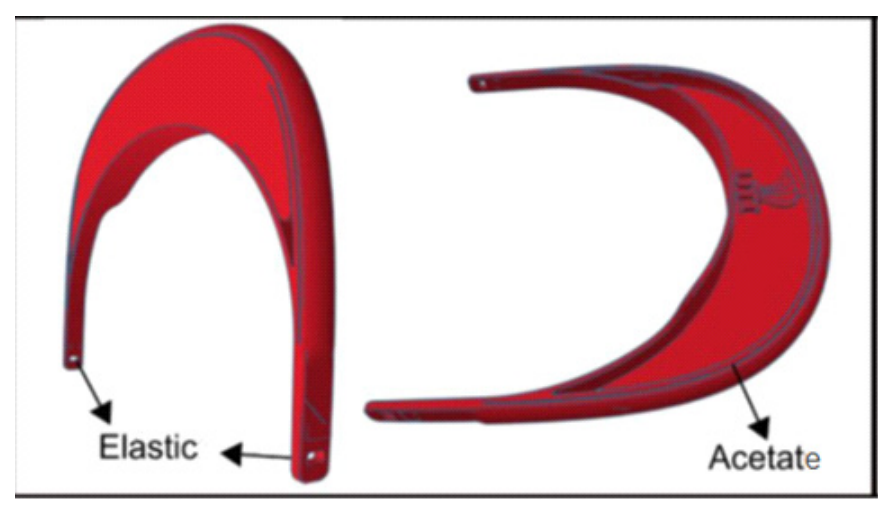

Figure 1. Facial protector design.

Source: Varela-Aldás [11].

The facial protectors can be manufactured from materials such as polycarbonate and polyester, polyvinyl chlorides (PVC), acetate and others. These are transparent and light biomaterials, which offer great optical capacity $[3,11]$.

Many oral and maxillofacial surgeons are already familiarized with 3D printing technology and develop an important role on the fabrication of facial protectors for health professionals who work in the front line of the Covid-19 combat [14].

For the fabrication of facial shields, there are 4 phases: The design of the shield (or download of a previously made project); The digital preparation (conversion of the file to the language to be used on the $3 \mathrm{D}$ printer - important step to ensure the quality of the product and the printing velocity); the printing itself; and, finally, the assembly, on which handcraft materials, such as velcro and foam are used [14].

The time needed for the manufacture of the shields varies according to the velocity of the printer, the size of the beak, the hight of the extruded layer and the size of the item to be printed. The balance between these variables must be kept, because changes may interfere on the quality of the final printed object [14].

The fabrication cost of the shields, however, depends on the materials used and, on the durability, intended for them. It is recommended the printing of several shields together, so that there is a reduction on the total cost [14].

Other items that were in shortage on the hospitals due to the pandemic, especially in Italy, were masks and hoods used on non-invasive ventilation for the breathing 
support. Despite the fact that some items were subject to copyrights and patent coverages, the patients' life and death situation may justify the use of intellectual property for the reproduction, in times of crises. An example is the fabrication of 3D prototypes of Venturi ${ }^{\circledR}$ valves. The " $T$ " connectors, that allow the use of the same invasive mechanical ventilator machine for more than one patient, in extraordinary cases, are also examples of items that can be manufactured by tridimensional technology, in case the original products are not being correctly distributed [1].

Although it is preferable that mechanical ventilators and their parts are acquired through their manufacturing companies, during the crises, many places are not being correctly supplied, such as the United States and Europe. Thus, a solution found was the use of 3D printed separators of ventilators and adjustable flux control valves, that allows the use of one ventilator for more than one patient, with different oxygen flux needs [1,3].

On the lab, it was attested that this device allows the use of up to 7 patients, not compromising the ventilation performance, when connected to a tube of up to $6 \mathrm{~m}$ of length. However, the confusing tube set may lead to human error [16].

The facial masks are also extremely important PPEs so that health professionals may care for contaminated patients with greater safety and, also due to the sanitary crises, there was a shortage of them in many hospitals. Due to the situation many 3D prototypes were developed and tested by users, researchers and health professionals, with different grades of success [1].

The N95 masks are indicated for health professionals use during the consults of COVID-19 patients and 3D printing can be used to produce designs that guarantee comfort to the users when using them, through exact facial parameters digitalization, which allows to personalize the contact pressure of the mask with the face $[3,5]$.

The standard N95 is constituted of a semirigid light material resistant to fatigue. Its clear composition could cause significant distortion of the 3D printer's parts after cooled. Thus, an elastomeric thermoplastic material that could be 3D printed was projected, that besides allowing a better printing and flexibility capacity of the mask, allows to personalize it for a better adjustment [3].

There are still other mask prototypes, such as the Cooper3D NanoHack ${ }^{\circledR}$ mask - that, despite being recyclable and reusable, possesses many limitations, the HEPA ${ }^{\circledR}$ mask and a similar project proposed by the Chinese company Creality; the Lowell Makes $₫$ mask and the creative project Flexible Mask Valvy ${ }^{\circledR}[1,10]$.

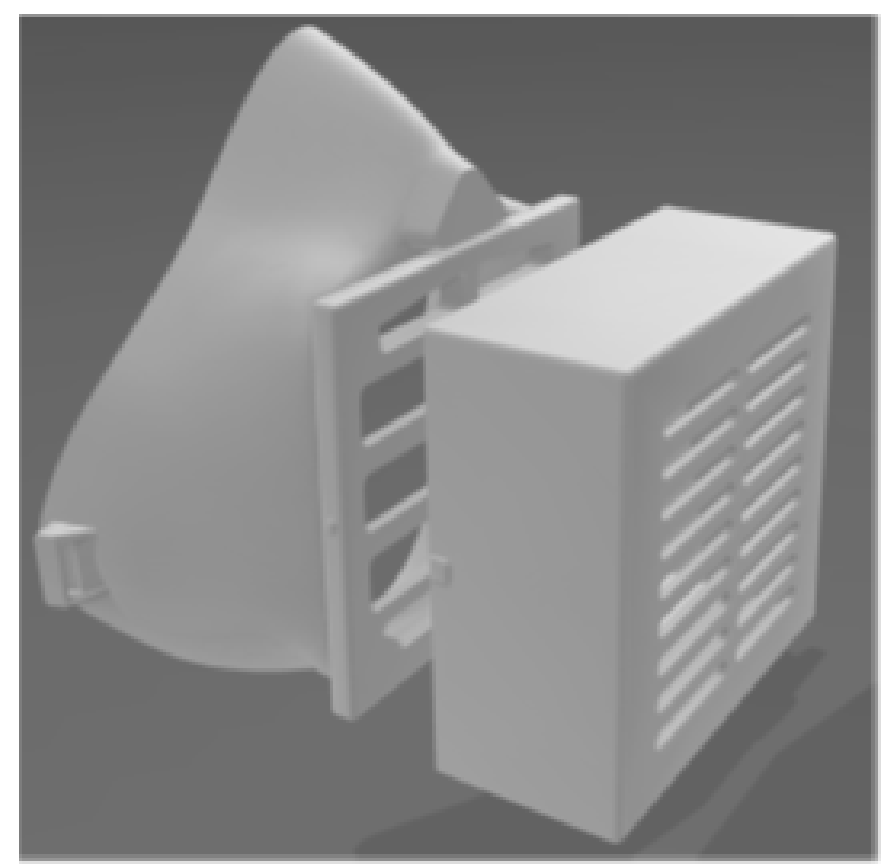

Figure 2. HEPA mask with box to insert filter. Source: Tino et al. [1].

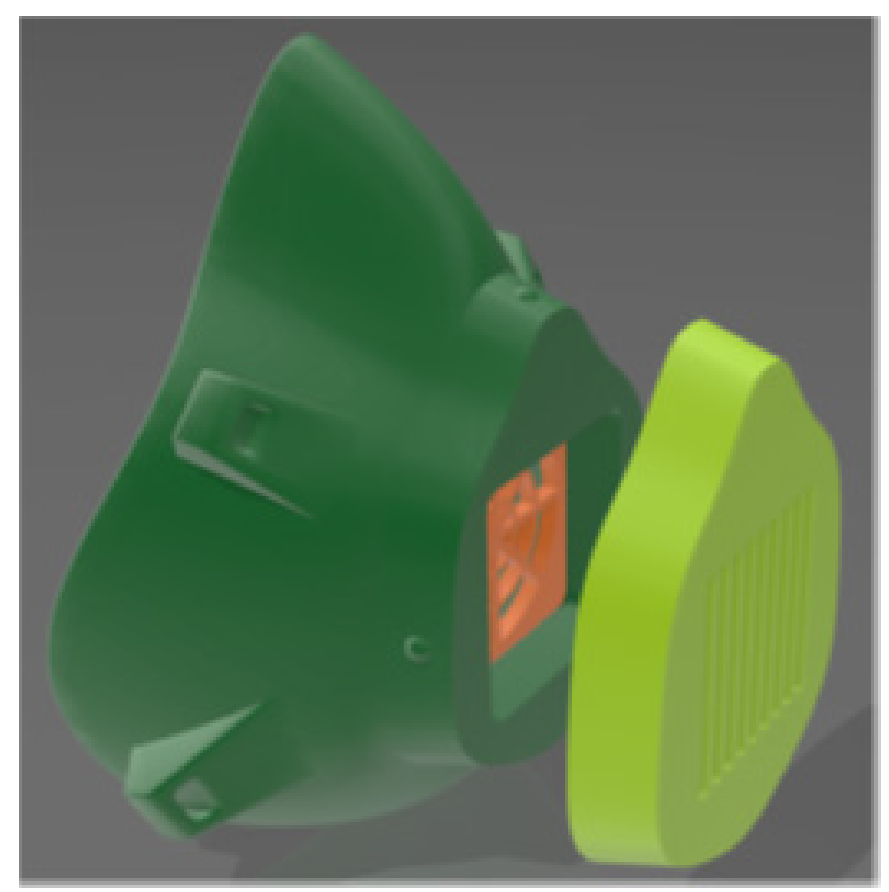

Figure 3. Lowell Makes mask.

Source: Tino et al. [1]. 
It is important to point out that masks, as indispensable items for the protection of the professionals, need to receive approval and regulation prior to the use, because many of them can't offer the same level of protection as a barrier, the same resistance to fluids or the same control of infection [12].

Another application of 3D printing on the pandemic context is on the manufacture of nasal and oropharyngeal flexible swabs, needed for the execution of tests for virus detection in patients with suspicion of infection. These can be manufactured in a fast way and supply efficiently the deficit of the health systems $[3,13]$.

A less quoted employment of 3D printing on the health area is on the fabrication of medicine, using printers of molten filament, ink-jet, extrusion and powder extrusion. Although there are no specific medication or vaccine for SARS-CoV-2, many antivirals may be fabricated through this technology [3].

The need of disinfection of the printed equipment is necessary, especially the PPEs, using substances that vary from alcohol to quaternary ammonium compound. The swabs used on tests to detect the virus, in case they are reusable, should be sterilized according to the specifications of the manufacturer, regarding the materials used to print them [1].

Besides the point of the tests, cost, processing time and workforce are limitations to the fabrication of the equipment printed in 3D [3].

Table 1. Application of 3D printing on the combat against the new coronavirus.

\begin{tabular}{|c|c|c|c|}
\hline Author/year & Local of the study & Company/Institution involved & Fabricated product / project available \\
\hline \multirow[t]{2}{*}{ Flanagan \& Ballard [9] } & USA & Prusa Reseach & Free design of Facial Protectors. \\
\hline & & Ford Motors & Production of around 1 million facial protectors per week. \\
\hline \multirow[t]{9}{*}{ Tino et al. [1] } & USA & Global Community of 3D printing & $\begin{array}{l}\text { Collection in Evolution of models ready to be printed and links for } \\
\text { the relevant resources } \\
\text { Reusable PPE projects: Facial protectors splash water proof, } \\
\text { surgical masks N95 masks, N90 masks, covers for the } \\
\text { air purifying ventilator, Hoods Ventilators, Air purifying } \\
\text { Controllers, Copper3D mask, NanoHack, mask with filter HEPA } \\
\text { (High Efficiency Particulate Arrestance), Lowell Makes masks, } \\
\text { Flexible Mask Valvy, Snorkel mask. }\end{array}$ \\
\hline & & & $\begin{array}{l}\text { Methods for Venturi valve fabrication, key-components of the } \\
\text { respiratory support equipment. }\end{array}$ \\
\hline & & $\begin{array}{l}\text { Food And Drug Administration } \\
\text { (FDA) }\end{array}$ & $\begin{array}{l}\text { Ventilator divisor project, for the use of one ventilator to several } \\
\text { patients. } \\
\text { Illinois Rapid-Vent project: prototype of emergency respiratory } \\
\text { ventilator. }\end{array}$ \\
\hline & & USA Veterans Association & Separator of ventilators and valves of adjustable flux control \\
\hline & & Thingiverse: user Kvatthro & project, such as the no2covid-ONE valve, capable of adapting one \\
\hline & & Creality & ventilator to several patients with different oxygen needs. \\
\hline & & Prusa Research. & \\
\hline & & & $\begin{array}{l}\text { Doorknobs accessories project, which avoids skin-surface direct } \\
\text { contact. }\end{array}$ \\
\hline & & Startup Isinnova & \\
\hline \multirow[t]{4}{*}{ Ishack \& Lipner [3] } & USA & & $\begin{array}{l}\text { Fabrication of } \mathrm{N} 95 \text { masks and designs of customized sealing, for } \\
\text { the improvement of comfort and mask adjustment. }\end{array}$ \\
\hline & & & Fabrication of nasal and oropharynx swabs destined to tests. \\
\hline & & & Systems of valve for ventilators of unique use project. \\
\hline & & & Possibility of printing pills and medication used to fight COVID-19. \\
\hline Jorge et al. [4] & Brazil & Community of makers & $\begin{array}{l}\text { Face Shield for Life 3D Project - manufacture and hygiene of } \\
\text { facial protectors for distribution on the Department of Health and } \\
\text { public hospitals in Salvador, BA. }\end{array}$ \\
\hline
\end{tabular}


Table 1. Application of 3D printing on the combat against the new coronavirus.

\begin{tabular}{|c|c|c|c|}
\hline Author/year & Local of the study & Company/Institution involved & Fabricated product / project available \\
\hline Castaneda [13] & Brazil & $\begin{array}{l}\text { National network of } 3 D \text { printing } \\
\text { laboratories of the Sistema Único } \\
\text { de Saúde (SUS) - Brazilian public } \\
\text { health system. }\end{array}$ & $\begin{array}{l}\text { Development and fabrication of facial shields, technical prototype } \\
\text { of ventilator mask with filter element, hood with sealing system, } \\
\text { reusable surgical masks, adaptors for a greater comfort when } \\
\text { using facial masks, protective glasses and mechanical ventilator } \\
\text { components. }\end{array}$ \\
\hline Varela-Aldás [11] & Ecuador & Tinkercard/Ultimaker Ultra & $\begin{array}{l}\text { Adapted facial protectors Project (production of around } 30 \\
\text { protectors per filament roll, each unit costs } \cup \$ 1,125 . \text {.). }\end{array}$ \\
\hline Swennen et al. [5] & Belgium & 3D Infinity & $\begin{array}{l}\text { 3D customized protective mask, with two reusable components } \\
\text { (facial mask and filter support.) } \\
\text { Design of two disposable components (head fixation band and } \\
\text { filter membrane). }\end{array}$ \\
\hline Cox \& Koepsell [16] & USA & - & $\begin{array}{l}\text { Development of nasopharyngea swabs using glycol polyethylene } \\
\text { terephthalate filament. }\end{array}$ \\
\hline Greig et al. [8] & United Kingdom & Thingverse & $\begin{array}{l}\text { Adapter project to allow coupling of a standard anesthesia filter } \\
\text { Heat and Moisture Exchange (HME), to a diving mask, (it failed a } \\
\text { quantitative test, in need of adjustments). }\end{array}$ \\
\hline Larraneta et al. [12] & United Kingdom & $\begin{array}{l}\text { Volkswagen, Nissan, Ferrari, Airbus } \\
\text { and BMW. } \\
\text { Issinova. }\end{array}$ & $\begin{array}{l}\text { Fabrication of facial protectors, using Molten Deposition Modeling } \\
\text { (MDM), and surgical masks and N95 ventilators } \\
\text { Project of a new valve for oxygen masks. }\end{array}$ \\
\hline
\end{tabular}

\section{DISCUSSION}

On the race against time, 3D printing industry shows itself to be capable of giving supply to the health sector solving the PPEs crisis, by the manufacture of medical/ hospital supplements. Besides, the segment can support the industrial supply chains most affected by limitations on production and traditional import during the COVID-19 pandemic.

Starting from the research carried for the present study it was possible to observe a predominance of analysis made in the United States of America, making evident the possible relevance of this country as one of the most engaged in the development of projects and fabrication of equipment for the health sector, during the pandemic. The United Kingdom is also very active. The data corroborate the fact that these countries have great number of 3D printers [6].
Besides, it was observed that the most used projects, among the ones studied, were the ones that have the goal of manufacturing facial protectors/shields, even in Brazil, they are easily found in many online platforms of designs distribution [4,11-14]. It is advised to be multiple printing of shields at once, in order to have economy and reduction on the fabrication cost [14].

All the initiatives share the importance to act with caution, because not all designs shared online are read to be manufactured nor to be used by health professionals. The initiatives should always choose the printing of equipment which is safe and approved by regulation institutions, due to the emergency character of the moment [12].

Despite the sanitary regulation agencies, such as Food and Drug Administration (FDA), softened the standards of fabrication and use of these emergency Personal Protection Equipment, the 3D printing community 
is working with the intention of prioritizing the security of the equipment, which is extremely relevant to the professionals in the front line of the combat against the new coronavirus [1].

With the identification and implementation of improvements, it will be possible to verify the increase of the manufacture of hospital equipment for medical procedures related to the treatment of the disease and also the opening of opportunities for the development of new companies in the field, known worldwide as startups.

\section{CONCLUSION}

From a perspective of a model of future assistance, individuals, institution and companies within the $3 \mathrm{~d}$ printing field united with the goal of trying to supply the needs of the health system, above all the ones related to the lack of PPEs and equipment needed to the diagnose and treatment of patients with the new coronavirus. It can be concluded that the application of 3D printing in these initiatives was of great contribution for public health and additive industry.

\section{Collaborators}

J FRANÇA, conceptualization, methodology. GBBS BIONE and JMFO MELO, methodology, data curation, and writing - original draft. BCF VAJGEL and FR ALMEIDA and FQ PEREIRA, visualizacion, investigacion. BCF VAJGEL and RCJ Silveira, supervision and resources and revision.

\section{REFERENCES}

1. Tino R, Moore R, Antoline S, Ravi P, Wake N, lonita CN, et al. COVID-19 and the role of 3D printing in medicine. 3D Print Med. 2020;6(11):1-8. https://doi.org/10.1186/s41205-02000064-7

2. Moraes EB, Sanchez MCO, Valente GSC, Souza DF, Nassar PRB. Safety of health professionals in COVID-19 times: a reflection. Res Soc Dev. 2020;9(7): e13497383. https://doi. org/10.33448/rsd-v9i7.3832

3. Ishack S, Lipner SR. Applications of 3D printing technology to address COVID-19 related supply shortages. Am J Med. 2020;133(7):771-773. https://doi.org/10.1016/j. amjmed.2020.04.002

4. Jorge EF, Azevedo $V$, Fernandes A, Araújo M, Brito L, Ferraz F, et al. Face shield for life 3D: produção colaborativa, usando a comunidade de makers, dos protetores faciais padrão RC3 para os profissionais de saúde em Salvador. Cad Prospecção. 2020;13(12):513-525. http://dx.doi.org/10.9771/cp.v13i2\%20 COVID-19.36174

5. Swennen GR, Pottel L, Haers PE. Custom-made 3D-printed face masks in case of pandemic crisis situations with a lack of commercially available FFP2/3 masks. Int J Oral Maxillofac Surg. 2020;49(5):673-677. https://doi.org/10.1016/j. ijom.2020.03.015

6. Vordos N, Gkika D, Maliaris G, Tilkeridis K, Antoniou A, Bandekas DV, et al. How social media and 3D printing tackles the PPE shortage during COVID-19 pandemic. Saf Sci. 2020;130:1-7. https://doi.org/10.1016/j.ssci.2020.104870

7. Sousa Neto AR, Bortoluzzi BB, Freitas DRJ. Equipamentos de proteção individual para prevenção de infecção por SarsCov-2. J Manag Prim Healh Care. 2020;12(17):1-7. https:// doi.org/10.14295/jmphc.v12.985

8. Greig P, Carvalho C, El-Boghdadly K, Ramessur S. Safety testing improvised COVID-19 personal protective equipment based on a modified full-face snorkel mask. Anaesthesia. 2020;75(7):970-971. https://doi.org/10.1111/anae.15085

9. Flanagan ST, Ballard DH. 3D Printed Face Shields: A Community Response to the COVID-19 Global Pandemic. Acad Radiol. 2020;27(6):905-906. https://doi.org/10.1016/j acra.2020.04.020

10. Javaid M, Haleem A, Vaishya R, Bahl S, Suman R, Vaish A. Industry 4.0 technologies and their applications in fighting COVID-19 pandemic. Diabetes Metab Syndr. 2020;14(4):419-422. https://doi.org/10.1016/j.dsx.2020.04.32

11. Varela-Aldás J. Impresión 3D y COVID-19. Cienci América. 2020;9(2):51-57. https://doi.org/10.33210/ca.v9i2.292

12. Larrañeta E, Dominguez-Robles J, Lamprou DA. Additive manufacturing can assist in the fight against COVID-19 and other pandemics and impact on the global supply chain. 3D Print Addit Manuf. 2020;7(3):100-103. https://doi. org/10.1089/3dp.2020.0106

13. Castaneda L. Formação, pesquisa e extensão na educação profissional e tecnológica: rede nacional de laboratórios de impressão 3d no sus. RBEPT. 2020;4:215-224. https://doi. org/10.36524/profept.v4iEspecial.641

14. Amin D, Nguyen N, Roser SM, Abramowicz S. 3D printing of face shields during COVID-19 pandemic: a technical note. J Oral Maxillofac Surg. 2020;78(8):1275-1278. https://doi. org/10.1016/j.joms.2020.04.040

15. Harris M, Bhatti Y, Buckley J, Sharma D. Fast and frugal innovations in response to the COVID-19 pandemic. Nat Med. 2020;26:814-817. https://doi.org/10.1038/s41591020-0889-1

16. Cox JL, Koepsell SA. 3D-printing to address COVID-19 testing supply shortages. Lab Med. 2020;51(4):e45-e46. https://doi. org/10.1093/labmed/lmaa031 